\title{
Global Networks and Shared Administration
}

\author{
Paul Craig
}

\section{Introduction}

This chapter considers global networks and shared administration, both of which are central for an understanding of global administrative law. The discussion begins with an overview of some of the literature concerning regulatory networks. The focus then shifts to consideration of shared administration. Thus while regulatory networks have proliferated at the global level the legal and practical reality is that most operate through forms of shared administration at the regional and/or national level. The nature of this shared administration perforce varies depending on the particular global regime, but an understanding of its modalities is crucial when thinking about the role of global administrative law. This is exemplified in parts four and five of the chapter, which analyze the regime of shared administration as it pertains to the WTO regime and that of international standard setting, drawing out the practical and normative implications for administrative law. The very fact that so much global regulatory activity broadly conceived is operationalized through some form of shared administration leads naturally to the last part of the chapter, which considers the role that national administrative law may play in rendering such global activity accountable.

\section{Global Networks}


Global networks have been the focus of increased interest and research in recent years. ${ }^{1}$ Thus Anne-Marie Slaughter working from an international relations perspective considers the way in which networks have transformed the global political order. ${ }^{2}$

Terrorists, arms dealers, money launderers, drug dealers, traffickers in women and children, and the modern pirates of intellectual property all operate through global networks. So, increasingly, do governments. Networks of government officials - police investigators, financial regulators, even judges and legislators - increasingly exchange information and coordinate activity to combat global crime and address common problems on a global scale. These government networks are a key feature of world order in the twenty-first century, but they are underappreciated, undersupported and underused to address the central problems of global governance.

She explains how networks are a prevalent feature of the global order, ranging from the environment to security, from financial regulation to international trade and from policing to macro-economic policy. The networks are normally horizontal in nature, in the sense that the relevant players are commonly bankers, trade officials or environmental activists from different countries. Networks can however be vertical, existing between players at different levels within a supranational organization. The networks may be free-standing, external to any international organization, but they commonly also feature within such organizations. Slaughter adopts a broad view of network, using it to capture 'all the different ways that individual government institutions are interacting with their counterparts either abroad or above them'. ${ }^{3}$ She defines a network as a 'pattern of regular and purposive relations among like government units working across the borders that divide countries from one another and that demarcate the "domestic" from the "international" sphere'.

\footnotetext{
${ }^{1}$ K. Raustiala, 'The Architecture of International Cooperation: Transgovernmental Networks and the Future of International Law' (2002) 43 Virginia Journal of International Law 1.

${ }^{2}$ A-M. Slaughter, A New World Order (Princeton: Princeton University Press, 2004), p. 1.

${ }^{3}$ Ibid p. 14.

${ }^{4}$ Ibid p. 14.
} 
The networks perform different functions, although some networks may have more than one role. There are enforcement networks, designed to render enforcement more efficacious across international boundaries, thereby rendering compliance with international rules more efficacious. There are information networks, aimed at the exchange of information between governmental agencies or the like, on matters as diverse as security, the environment, policing, health, and fundamental rights, thereby facilitating international cooperation. The third category is the harmonization network, designed to foster closer uniformity in regulatory standards, which can thereby facilitate convergence on an issue, or help to ensure that divergence of view is informed by reasoned dialogue based on understanding of the other side's perspective.

Tim Büthe and Walter Mattli writing from the perspective of international political economy focus on regulatory output, distinguishing between four types of global rulemaking. The distinctions take account of whether the rulemaking is developed in public or private settings, and also whether the standard setters compete, or whether there is a dominant body that is 'the focal point for developing international standards in a given issue area'. This typology yields the four species of global rulemaking.

The first is public/governmental nonmarket standard-setting, whereby traditional intergovernmental organizations function as the non-market standard-setting body, as exemplified by bodies such as the Universal Postal Union which dates from 1874, the International Labour Organization founded in 1919, and the International Monetary Fund created in 1944.

The second strand of the typology assumes the form of public standard-setting bodies that operate in market competition, such that the standard is the result of competition between

\footnotetext{
${ }^{5} \mathrm{~T}$ Büthe, and W. Mattli, The New Global Rulers, the Privatization of Regulation in the World Economy (Princeton: Princeton University Press, 2011), p. 18.
} 
'legislatures or regulatory agencies of individual states and regional or minilateral standardsetting bodies'. ${ }^{6}$ This is exemplified by the competition that prevails between standards established by the US and the EU in relation to matters such as product safety, the environment and the like.

Market-based private international standard-setting constitutes the third mode of global rulemaking, the spur often being the slow pace of public initiatives, combined with the lack of technical expertise, more especially in fields where the pace of technological change is rapid. In these areas the rules are made by 'firms or other non-governmental bodies, competing individually or in small groups to establish their preferred technical solutions as the de facto standard', (Büthe and Mattli, 2011, p. 26), as exemplified by the information and technology sector, where Microsoft established the Windows operating system as the de facto global standard.

Non-market private international standard-setting completes the typology, and is characterized by an international non-governmental organization that is regarded as the focal institution for that type of rule-making. Prominent examples include the ISO, the International Organization for Standardization, the IEC, the International Electrotechnical Commission, and the ISAB, the International Accounting Standards Board. This type of rulemaking is increasingly important judged both in terms of the number of products covered and the impact of the rules that are made. Thus the standards will often be applicable to a range of products and compliance with the relevant criteria will often be required either to secure market access, or because the regulatory requirements are incorporated in national laws, directly or indirectly.

When we shift from the descriptive to the normative then the discourse becomes more contentious. The purpose of Slaughter's study is not merely descriptive, it is also explicitly

\footnotetext{
${ }^{6}$ Ibid p. 23.
} 
normative. Thus she argues that networks can be a positive force for good within the global order. They can foster convergence on an issue, or help to ensure that divergence of view is informed by reasoned dialogue based on understanding of the other side's perspective. Networks can improve compliance with international rules and increase international cooperation.

Slaughter is nonetheless mindful of the problems with networks, which relate both to input and output. Thus decision-making may be dominated by experts and enthusiasts, by technology and passion, to the exclusion of a broader spectrum of views. Networks may lack transparency, which exacerbates the preceding problem. Networks may also circumvent the normal rules of representative democracy, allowing policy to be developed without the imprimatur of the elected legislature.

Slaughter responds by proposing five principles to alleviate these concerns. ${ }^{7}$ Global deliberative equality is designed to counter the elitism/exclusion that can attend networks. The process of global governance is seen as a collective deliberation about common problems and hence all affected individuals, or their representatives, are entitled to participate. All government networks should therefore adopt clear criteria for participation that will be fairly applied. Legitimate difference entails the idea that difference of view 'reflects a desirable diversity of ideas about how to order an economy or society,,${ }^{8}$ with willingness to reconsider how an issue is dealt with at home, and respect different choices made by other societies. Thus legitimate difference 'enshrines pluralism as a basis for, rather than a bar to regulatory cooperation, leaving open the possibility of further convergence between legal systems in the form of mutual recognition or even harmonization, but not requiring it'. The third of

\footnotetext{
${ }^{7}$ A-M. Slaughter, A New World Order (Princeton: Princeton University Press, 2004), Ch. 6.

${ }^{8}$ Ibid p. 248.

${ }^{9}$ Ibid p. 249.
} 
Slaughter's principles is positive comity, which is a principle of affirmative cooperation between government agencies of different nations. It requires regulatory agencies to substitute consultation and active assistance for unilateral action and noninterference, as exemplified by international cooperation in relation to antitrust. The penultimate principle is checks and balances, with Slaughter providing the example of the relationship between national courts and the Community courts in the EU, and the hope that 'government institutions of the same type in different systems national and international, and of different types can check each other both vertically and horizontally'. ${ }^{10}$ Subsidiarity is the final principle: decisions should be taken as closely as possible to the citizen, with the consequence that most decisions should still be taken at national level, or even closer to the citizen if feasible.

Concerns about global and transnational networks are also apparent in the literature on global administrative law. Thus Benedict Kingsbury, Nico Krisch and Richard Stewart stress that underlying the emergence of global administrative law is the "vast increase in the reach and form of transgovernmental regulation and administration designed to address the consequences of global administration'. ${ }^{11}$ They note that global administrative bodies include formal intergovernmental regulatory bodies, informal intergovernmental regulatory networks and coordination arrangements, national regulatory bodies operating with reference to an international intergovernmental regime, hybrid public-private regulatory bodies, and some regulatory bodies exercising transnational governance functions of particular public significance'. Thus transnational networks and coordination arrangements are one type of global administration generating interest in global administrative law. The challenge is to

\footnotetext{
${ }^{10}$ Ibid p. 254.

${ }^{11}$ B. Kingsbury, N. Krisch, and R.B. Stewart, 'The Emergence of Global Administrative Law' (2005) 68 Law and Contemporary Problems 15, 16.
} 
consider how far administrative law precepts concerning matters such as procedural participation, transparency, reasoned decision-making, and judicial review, including substantive rationality or proportionality scrutiny, can be applied in such contexts. ${ }^{12}$

\section{Shared Administration}

While the concept of global networks has therefore received considerable attention, this has been less so in relation to the idea of shared administration. The two concepts might be treated inter-changeably, such that the term shared administration is simply used to describe a particular type of regulatory network, and vice-versa. While this is possible, it is of limited utility. There is little point in employing two terms to describe the same phenomenon, if the second adds nothing of substance to the first.

This chapter is predicated on the contrary assumption. It will be argued that the concept of shared administration has something distinctive to tell us about the nature of the relationship between the global, regional and national levels in the context of regulatory networks. It will also be argued that it has something to tell us about the normative and practical application of the precepts of global administrative law as they play out in reality in particular regulatory settings. Indeed it will be seen that it is only by paying closer attention than is customarily given to the type of shared administration that pertains in any particular

\footnotetext{
12 See, e.g., A. Aman, 'Globalization, Democracy and the Need for a New Administrative Law' (2003) 10 Indiana Jnl of Global Legal Studies 125; S. Cassese, 'Global Standards for National Administrative Procedure' (2005) 68 Law and Contemporary Problems 109; R. B. Stewart, 'The Global Regulatory Challenge to U.S. Administrative Law' (2005) 37 New York University Journal of International Law and Policy 695; A. von Bogdandy and P. Dann, 'International Composite Administration: Conceptualizing Multi-Level and Network Aspects in the Exercise of International Public Authority' (2008) 9(11) German Law Jnl 2013; S. Cassese, The Global Polity, Global Dimensions of Democracy and the Rule of Law (Sevilla: Global Law Press, 2012).
} 
instance that we can begin to make sense of the inter-relationship between national, regional and global administrative law.

The legal and administrative reality is that in many instances global administration and global networks operate by and through shared administration with authorities at national or regional level. Shared administration as employed here carries a variety of possible connotations, as the subsequent discussion will reveal. This includes the specific connotation developed in the context of the EU, viz two or more authorities operating at different levels have distinct administrative tasks enshrined in legislation, and both must discharge their respective tasks for the relevant policy to be implemented successfully. ${ }^{13}$

It is important at the outset to dispel any idea that insofar as there are problems concerning regulatory interaction between the global, regional and national orders that 'blame' should be placed at the door of the global order. This will not withstand examination. The practical and normative reality is more complex, there being issues of accountability that pertain to the national/regional level, and to the global level.

From the national perspective, regulators are more limited in what they can achieve, since they can only regulate conduct that falls within their jurisdiction, but there is also a disjunction between what Joanne Scott has aptly termed 'regulatory jurisdiction and regulatory impact', ${ }^{14}$ in the sense that states are not accountable to other states that are affected by their domestic regulation, thereby creating a horizontal accountability gap, since

\footnotetext{
${ }^{13}$ Committee of Independent Experts, Second Report on Reform of the Commission, Analysis of Current Practice and Proposals for Tackling Mismanagement, Irregularities and Fraud (10 September 1999); P. Craig, 'Shared Administration and Networks: Global and EU Perspectives', in G. Anthony, J-B. Auby, J. Morison and T. Zwart (eds.), Values in Global Administrative Law, Essays in Honour of Spyridon Flogaitis and Gerard Timsit (Hart, 2011), Chap. 4.

${ }^{14}$ J. Scott, 'Cooperative Regulation in the WTO: The SPS Committee', Global Law Working Paper, 3/06, Hauser Global Law School Program-NYU School of Law.
} 
the affected states have no voice in such measures. Viewed from this perspective, global regulatory regimes can help to reduce this accountability gap in national regulation, by encouraging horizontal and vertical integration of domestic regulatory systems. ${ }^{15}$

From the global perspective, there are, however, accountability problems that pertain to the very global regulatory regimes established to ameliorate the effect of domestic regulation. Thus while some such regimes are accountable to national governments through national representatives on such bodies, this is indirect and of limited efficacy. It is moreover only applicable to certain global regulatory regimes, and merely reconnects each member of the global body to its own national community. The development of precepts of global administrative law is one way of alleviating the accountability problem at global level, albeit not the only one. Crafting the appropriate tools is however no easy task, more especially when one moves from the level of abstract principle to conceptual and operational realization. ${ }^{16}$

\section{Global Networks and Formal Shared Administration: The WTO}

\section{(a) The WTO Schema of Shared Administration}

Some global regulatory networks take effect through formal shared administration, embodied in binding legal rules, as exemplified by the WTO schema. A common pattern in the WTO is that the agreement establishes detailed regulatory criteria, which are triggered and applied by

\footnotetext{
${ }^{15}$ S. Battini, 'The Proliferation of Global Regulatory Regimes', in S. Cassese (ed.), Global Administrative Law, A Research Handbook, Pt. I, Chap. 2.

${ }^{16}$ P. Craig, UK, EU and Global Administrative Law: Foundations and Challenges (Cambridge: Cambridge University Press, 2015), Chap. 6.
} 
national administrative authorities, and in that sense the agreements operate from the 'bottom up' ${ }^{17}$ subject to possible oversight by administrators and adjudicators at the WTO level.

This form of shared administrative arrangement is driven in part by political considerations, since WTO Members would not view with equanimity a WTO official having the initial responsibility for application of the regulatory criteria within its state. It is also driven by more practical considerations, viz that the WTO does not possess the bureaucracy necessary to undertake such work across all WTO Members, or in relation to all WTO Agreements.

This pattern of administration is evident in the Anti-Dumping Agreement, Article 1 of which provides that an 'anti-dumping measure shall be applied only under the circumstances provided for in Article VI of GATT 1994 and pursuant to investigations initiated and conducted in accordance with the provisions of this Agreement'. Articles 2-4 deal respectively with the meaning of dumping, the determination of injury and the definition of the domestic industry.

Article 5 is concerned with the investigation, which is initiated by complaint from the domestic industry. It is then incumbent on the 'authorities' to 'examine the accuracy and adequacy of the evidence to determine whether there is sufficient evidence to justify the initiation of an investigation', ${ }^{18}$ and if there is to make the determination as to whether dumping has occurred. There are detailed rules as to the procedures that must be followed by the authorities when conducting such an investigation, ${ }^{19}$ followed by equally detailed provisions as to the remedies that can be imposed, including provisional measures, price

\footnotetext{
${ }^{17}$ G. della Cananea, 'The European Union's Mixed Administrative Proceedings' (2004) 68 Law and Contemporary Problems 197.

${ }^{18}$ Art. 5(3) Anti-Dumping Agreement.

${ }^{19}$ Ibid Art. 6.
} 
undertakings and anti-dumping duties. ${ }^{20}$ The centrality of national authorities to the investigative exercise is further emphasized by the obligation in Article 13 to maintain an effective and independent regime of judicial review.

The shared administrative input from the WTO takes the form of the Committee on Anti-Dumping Practices, composed of representatives from each Member, which meets not less than twice per year. It serves, inter alia, as a forum for the negotiated resolution of disputes between Members concerning the imposition of anti-dumping duties. ${ }^{21}$. The emphasis is on consultative solution, but with recourse to the WTO Dispute Settlement Body and the establishment of an adjudicative panel should negotiation fail. ${ }^{22}$

The same pattern of shared administration is evident in the Agreement on the Application of Sanitary and Phytosanitary Measures, although in this instance the vertical shared administration as between national authorities and the WTO is complemented by a horizontal dimension, insofar as the SPS Agreement forges explicit links with other international organizations. The SPS Agreement gives Members the right to take sanitary and phytosanitary measures necessary for the protection of human, animal or plant life or health, provided that such measures are not inconsistent with the provisions of the SPS Agreement. ${ }^{23}$ The measures must not impose restrictions greater than necessary, and must not discriminate arbitrarily or unjustifiably as between Members. ${ }^{24}$

The SPS Agreement goes to considerable lengths to foster harmonization in the application of such measures, by requiring Members to base such measures on international

\footnotetext{
${ }^{20}$ Ibid Arts. 7-9.

${ }^{21}$ Ibid Arts. 16-17.

${ }^{22}$ Ibid. Art. 17.

${ }^{23}$ Art. 2(1) SPS.

${ }^{24}$ Ibid Arts. 2.2-2.3.
} 
standards, with special emphasis on those made by the Codex Alimentarius Commission. ${ }^{25}$ It also mandates mutual recognition, requiring acceptance of SPS measures from other Members as equivalent, even if they differ from the state of import, provided that the exporting Member demonstrates that its measures achieve the importing Member's appropriate level of sanitary or phytosanitary protection. ${ }^{26}$ There are provisions requiring that the SPS measures imposed by a Member are subject to risk assessment, the nature of which is set out in detail. ${ }^{27}$ So too are the control, inspection and approval procedures. ${ }^{28}$

It is the importing state Members that are charged with the primary administration of the SPS regime, which is unsurprising given that it is their measures that are in issue. This is subject to the injunction that such 'Members are fully responsible under this Agreement for the observance of all obligations set forth herein', and 'Members shall formulate and implement positive measures and mechanisms in support of the observance of the provisions of this Agreement by other than central government bodies'. ${ }^{29}$

The administrative schema at WTO level is analogous to that seen in the context of the Anti-Dumping Agreement. Thus there is a Committee on SPS Measures, which is designed to facilitate consultation between Members concerning contentious SPS measures, and also foster harmonization initiatives. The Committee is charged with maintaining close contact with relevant international organizations in the field of sanitary and phytosanitary protection, especially with the Codex Alimentarius Commission, the International Office of Epizootics, and the Secretariat of the International Plant Protection Convention. ${ }^{30}$ Dispute

\footnotetext{
${ }^{25}$ Ibid Art. 3.

${ }^{26}$ Ibid. Art. 4.

${ }^{27}$ Ibid Art. 5.

${ }^{28}$ Ibid Annex C.

${ }^{29}$ Ibid Art. 13.

${ }^{30}$ Ibid Art. 12.
} 
resolution through consultation mediated by the Committee is complemented by possible recourse to the WTO dispute settlement regime of panels and the Appellate Body, as regulated by the Dispute Settlement Understanding. ${ }^{31}$

\section{(b) The Practical and Normative Consequences for Administrative Law}

The WTO regime has several important implications for the interaction between the global and national legal orders insofar as administrative law is concerned.

In terms of input legitimacy, a powerful network such as the WTO has the legitimacy that flows from the fact that it has been duly established by Treaty, which specifies in detail the powers and duties of its members. There are contentious issues relating to the adequacy of the traditional mechanisms for Treaty making, concerning matters such as the balance between legislative and executive power in the negotiation and ratification of such agreements, but those issues are not specific to the WTO. There are, however, highly-charged issues that relate more specifically to the WTO, such as the influence of industry representatives during negotiations leading to the conclusion of the Uruguay Round of reforms 1986-94, and the balance between economic and non-economic concerns embodied in the resulting agreements. ${ }^{32}$

In terms of transparency, this is enhanced by the fact that the WTO regime is enshrined in a series of formal agreements, which are readily available for those interested or affected. There are to be sure difficult issues of interpretation in particular WTO agreements, but the prevalence of such difficulties is not noticeably greater than when analogous matters are regulated at national or regional level. In the WTO context, but certainly not in all other

\footnotetext{
${ }^{31}$ Art. 11 DSU.

${ }^{32}$ L. Wallach, 'Accountable Government in the Era of Globalization: The WTO, NAFTA and the International Harmonization of Standards' (2002) 50 University of Kansas Law Review 823, 824-6.
} 
areas of global regulation, a quid pro quo of the limitation of national regulatory autonomy is that Members know their obligations and that affected firms can lock onto the regulatory obligations imposed on Members at national level.

There are nonetheless transparency concerns that relate to, for example, the dispute settlement process. The fact that panel deliberations are confidential is not in itself unusual, since this is the norm for most adjudicative bodies. ${ }^{33}$ Nor is the fact that the opinions expressed in the panel report by individual panellists are anonymous, ${ }^{34}$ since this is the norm in the majority of civil law regimes. The instructions for panel hearings provide, however, that it 'shall meet in closed session' and that the parties only attend when invited to do so, although they are guaranteed presence for the entirety of the argument. ${ }^{35}$ The hearing is moreover largely confined to the parties to the dispute, with provision for other WTO Members with a 'substantial interest' in a matter before a panel to have an opportunity to be heard and make submissions. ${ }^{36}$ Citizens and citizen groups do not have the right to participate, but they may submit an amicus brief that can be accepted at the discretion of a panel. ${ }^{37}$ It seems however that the Appellate Body will not accept such briefs unless they are appended to the submissions of a formal party to the dispute. ${ }^{38}$

In terms of judicial review, the WTO commonly makes provision for such oversight at two levels, the national and the global, although the precise admixture will depend on the particular WTO agreement that is in issue. Thus particular WTO agreements impose a

\footnotetext{
${ }^{33}$ Art. 14(1) DSU.

${ }^{34}$ Ibid Art. 14.3.

${ }^{35}$ Ibid Appendix 3, paras. 3, 10.

${ }^{36}$ Ibid Art. 10(2).

${ }^{37}$ United States-Import Prohibitions of Certain Shrimp and Shrimp Products, 12 Oct. 1998, WT/DS58/AB/R.

${ }^{38}$ J.L. Dunoff, 'Constitutional Conceits: The WTO's 'Constitution' and the Discipline of International Law' (2006) 17 European Journal of International Law 647.
} 
requirement of independent judicial review at national level, the efficacy of which will perforce depend on more general considerations concerning the efficacy of such review in that state. The approach in other WTO Agreements, such as TRIPS dealing with intellectual property, is to mandate that national judicial authorities hear complaints from private parties concerning violation of the TRIPS Agreement. ${ }^{39}$

The agreements will in any event commonly mandate due process at national level, and circumscribe the exercise of substantive discretionary choice by national authorities through requirements relating inter alia to mutual recognition, non-discrimination, proportionality, risk assessment and the like. If a Member is dissatisfied with the outcome at national level then it can seek a negotiated solution via the WTO, or trigger the dispute settlement mechanism and attendant judicial review by WTO panels and the Appellate Body. The WTO dispute settlement system is tilted toward market liberalization in that it creates opportunities to challenge government measures as trade barriers, but not to challenge them for providing insufficient regulatory protection'. ${ }^{40}$

In regulatory terms, the effect of the WTO schema is complex. It closely circumscribes the options available to Members, narrows representative democratic choice at national level. It thereby prevents the legislature opting for protectionism, and limits legislative choice more generally by providing, for example, that measures restrictive of trade on sanitary grounds are not more trade restrictive than required. ${ }^{41}$ This is subject to the obvious caveat that the national legislature will have approved membership of the WTO in accord with whatever constitutional arrangements pertain in that state. The circumscription of

\footnotetext{
${ }^{39}$ Arts. 41-42, 51-52 TRIPS.

${ }^{40}$ Shaffer, G., 'How the WTO Shapes Regulatory Governance', University of California, Irvine, Legal Studies Research Paper Series No. 2014-53, p. 5.

${ }^{41}$ Art.5.6 SPS.
} 
such legislative choice is designed, inter alia, to foster accountability by ensuring that the economic choices of a Member take account of the interests of other Members in the areas covered by the WTO agreements. The national executive's role in relation to the legislature is enhanced because the executive will represent the Member at WTO level, whereas the legislature has no seat at the WTO. The global regulatory package is difficult to amend for the reasons set out above.

While the WTO regime entails trade liberalization it would be mistaken to conceive of this simply in terms of deregulation. The reality is that it involves 'not so much deregulation but re-regulation to facilitate, oversee, and check capitalism, involving both public and private actors', with the result that 'regulatory governance, quintessentially seen in nation-state terms, has become transnationalized' ${ }^{42}$ The assumption that trade liberalization will lead to a regulatory race to the bottom must also be qualified. This is in part because some WTO agreements allow a Member to maintain standards higher than the international norm. ${ }^{43}$ It is in part because the WTO can contribute to a 'race to the top', since producers 'may comply with the standards of the most important trading partner which may in fact be quite high, which, in the WTO context, will likely be either a U.S. or an E.U. standard (known as the "California effect" or the "Brussels effect"), ${ }^{44}$ It is in part because the WTO regime itself mandates new agencies and bureaucracies at national level to implement WTO regulatory norms. The consequence as Greg Shaffer points out is that, ${ }^{45}$

[T] he WTO forms part of broader processes of transnational legal ordering that shapes the boundary between the market and the state. On the one hand, WTO tariff bindings and nondiscrimination norms enlarge markets by catalyzing product competition across borders. On the

\footnotetext{
${ }^{42}$ Ibid p. 3.

${ }^{43}$ Art. 3.3 SPS.

${ }^{44}$ Shaffer, G., 'How the WTO Shapes Regulatory Governance', University of California, Irvine, Legal Studies Research Paper Series No. 2014-53, p. 8.

${ }^{45}$ Ibid. p. 10.
} 
other hand, WTO norms directly and indirectly spur new international and transnational standard-setting initiatives by international organizations, nation states, and private actors. As a result, WTO processes both expand markets and spur regulation to become more transnational in scope, in the process arguably expanding regulatory governance more than constraining it.

\section{Global Networks and Shared Administration: The ISO}

\section{(a) The ISO Schema of Shared Administration}

There is an increasing literature that reveals the importance of bodies such as the ISO. Thus as we have seen Büthe and Mattli have revealed the importance of standard-setting bodies such as the ISO, the International Organization for Standardization, the IEC, the International Electrotechnical Commission, and the ISAB, the International Accounting Standards Board. This type of rule-making is increasingly important judged both in terms of the number of products covered and the impact of the rules that are made. Thus the standards will often be applicable to a range of products and compliance with the relevant criteria will often be required either to secure market access, or because the regulatory requirements are incorporated in national laws, directly or indirectly. ${ }^{46}$ The significance of such standards is thrown into sharp relief by the output of the ISO and IEC. ${ }^{47}$

Jointly, they account for about 85 per cent of all international product standards. ISO's standards include standards for freight containers, paints and varnishes, screw heads, corrosion protection, thermal performance and air quality measurement, as well as the "ISO 9000" series management standards. IEC standards specify, for instance, safe and effective radiation dosages for x-ray machines, the standard dimensions and other characteristics of audio CDs and battery sizes, as well as methods to measure electromagnetic interference and thresholds to safeguard against it, so that the operation of one piece of electric equipment, such as a vacuum cleaner or microwave, does not interfere with the operation of other crucial equipment such as pacemakers or computerized security systems. For most industries, either ISO or IEC is clearly the focal point for setting international product standards, and where their areas of expertise overlap they collaborate closely.

\footnotetext{
${ }^{46}$ W. Mattli, and T. Büthe, 'Setting International Standards: Technological Rationality or Primacy of Power' (2003) 56 World Politics 1.

${ }^{47}$ T. Büthe, and W. Mattli, The New Global Rulers, the Privatization of Regulation in the World Economy (Princeton: Princeton University Press, 2011), pp. 29-30.
} 
The sense of shared administration that pertains in the International Organization for Standardization is very different from that in the WTO, but it is real nonetheless, notwithstanding the fact that it is not embodied in formal legal rules. ISO Administration is shared in a double sense: its constituent members are national standards agencies who help to decide on the applicable standards within the ISO, and it is these same national agencies that promote ISO standards in their own country.

The ISO was officially born in 1947, following a meeting of delegates from 25 countries to discuss the future of International Standardization. It is a non-governmental organization, with a Central Secretariat that now employs circa 150 people, as compared with 5 in the early 1950s, and members from 165 countries. It has produced in excess of 19,500 standards, which cover pretty much all aspects of business, food and technology.

The national standards bodies constitute the ISO membership and they represent the ISO in their country. The ISO Statute stipulates that 'the member bodies shall be those national standards bodies most broadly representative of standardization in their respective countries and which have been admitted into the Organization in accordance with procedures defined by Council'. ${ }^{48}$ It is the full members that influence ISO standards development and strategy by participating and voting in ISO technical and policy meetings. It is the full members that also sell and adopt ISO standards nationally. There are correspondent members that attend ISO meetings as observers, and can also sell such standards nationally, whereas subscriber members merely keep up to date with ISO business. ${ }^{49}$

The ISO General Assembly decides on strategic objectives, but meets only once per year. The real work of the ISO is done at the executive level by the Central Secretariat and

\footnotetext{
${ }^{48}$ Art. 3.1.1 ISO Statute.

${ }^{49}$ Ibid Art. 3.1.2.
} 
the ISO Council as assisted by a number of committees, and at the technical level by technical committees, which devise the standards, overseen by a technical management board. There are in excess of 250 such committees, composed of technical experts, as well as representatives of industry, NGOs and governments. ${ }^{50}$ ISO full members decide whether they would like to be a participating member of a particular committee, or merely an observer. ${ }^{51}$ Consumer interests are taken into account in standard setting through: consumer representatives of national members in the technical committees; the ISO Committee on Consumer Policy; ${ }^{52}$ and through Consumers International, a federation of consumer groups from around the world. ${ }^{53}$

\section{(b) The Practical and Normative Consequences for Administrative Law}

The schema of private standard setting embodied in the ISO is very different from the state dominated form of global regulation in the WTO, and this is reflected in different senses of shared administration that prevail in the two settings. These differences have important practical and normative consequences for administrative law.

In terms of input legitimacy, the private standard setting undertaken by ISO is predicated on consensual agreement formally embodied in the ISO Statute, reflective of the simple legal precept that it is open to individuals or private organizations to create a legal entity operating at the global level, which will be formally registered in a particular country. This is of course only part of input legitimacy, albeit the most formal part. Input legitimacy in this context also connotes the idea that those who wish to partake in the standard setting

\footnotetext{
${ }^{50}$ http://www.iso.org/iso/home/standards_development/list_of_iso_technical_committees.htm.

${ }^{51}$ http://www.iso.org/iso/home/about/iso_members.htm.

${ }^{52}$ http://www.iso.org/iso/home/about/iso-and-the-consumer/copolco.htm.

${ }^{53}$ http://www.consumersinternational.org/who-we-are/about-us/.
} 
process must come to the table with the requisite technical, scientific expertise. This thereby 'reinforces the transnational standard-setting body's legitimacy, which is based on technical expertise', which by 'rendering other (political or economic) arguments impermissible and illegitimate', thereby 'safeguards the transnational body against overt and political and especially government interference'. 54

There is a further dimension to input legitimacy in the ISO context, which is the most controversial. The ISO is private in formal terms, in the sense that it is non-governmental, but compliance with the relevant standards will often be required either to secure market access, or because the regulatory requirements are incorporated in national or EU laws, directly or indirectly. We will explore this more fully below, when discussing the regulatory dimension of the ISO, and its linkage with national and EU standardization bodies. Suffice it to say for present that the fact that these 'private' standards are then transformed into 'public' obligations or options perforce raises legitimacy concerns. Thus while bodies such as the ISO emphasize the technical, scientific nature of the inquiry, the reality is that standard setting inevitably entails matters of risk assessment and cost/benefit analysis, which are not and cannot be value free. This in turn generates concerns as to who has 'voice' in the standard setting process, and the extent to which consumer interests and those of the developing world are adequately represented. This explains the ISO's efforts to portray the way in which such interests are taken into account, ${ }^{55}$ although the extent of such input and its effectiveness in the face of industry representatives have been doubted. ${ }^{56}$

\footnotetext{
${ }^{54}$ T. Büthe, and W. Mattli, The New Global Rulers, the Privatization of Regulation in the World Economy (Princeton: Princeton University Press, 2011), p. 45. http://www.iso.org/iso/home/standards_development/who-develops-iso-standards.htm; http://www.iso.org/iso/home/about/iso-and-the-consumer/copolco.htm.

${ }^{56}$ L. Wallach, 'Accountable Government in the Era of Globalization: The WTO, NAFTA and the International Harmonization of Standards' (2002) 50 University of Kansas Law Review 823, 836-9; S. Shapiro, 'International
} 
In terms of transparency, the ISO fares well when judged by the transparency of the results. Its standards are readily available to view, which is unsurprising given that the ISO seeks to sell the standards thus promulgated. ${ }^{57}$ The formal process by which such standards are adopted is also clear, the lead being taken by a panel of experts, within a technical committee. When the need for a standard is established, the experts negotiate a draft standard, which is then shared with ISO members who comment and vote on it. It may be sent back to the technical committee if consensus is not forthcoming. ${ }^{58}$ The catalyst for development of a new standard normally comes from industry or a stakeholder group, rather than from within the ISO. While the standard making process is transparent in the preceding sense it is nonetheless evident that those proposing the standard, together with those stakeholders best informed and organized have a very considerable influence on the draft that emerges from the technical committee and hence on the resulting standard. ${ }^{59}$ It is also important to recognize that interested parties may have scant information that a standard is being developed and hence are unable to contribute to the process,${ }^{60}$ an issue that will be returned to below.

In terms of judicial review, we need to tread carefully. There is no judicial organ within the ISO that subjects its work to review, either procedurally or substantively. This does not mean that the ISO fails to comply with procedural precepts such as due process, or

Trade Agreements, Regulatory Protection, and Public Accountability' (2002) 54 Administrative Law Review $435,442,449-50$.

${ }^{57}$ http://www.iso.org/iso/home/store.htm; http://www.iso.org/iso/home/store/catalogue ics.htm.

${ }^{58}$ http://www.iso.org/iso/home/standards development.htm.

${ }^{59}$ T. Büthe, and W. Mattli, The New Global Rulers, the Privatization of Regulation in the World Economy (Princeton: Princeton University Press, 2011), pp. 162-86.

${ }^{60}$ S. Shapiro, 'International Trade Agreements, Regulatory Protection, and Public Accountability' (2002) 54 Administrative Law Review 435; R. B. Stewart, 'Remedying Disregard in Global Regulatory Governance: Accountability, Participation, and Responsiveness' (2014) 108 American Journal of International Law 211. 
substantive precepts such as rationality. It does mean that there is no judicial body within the ISO to which appeal can be made by a party affected by a standard who seeks to argue that it is infirm in such respects. If judicial recourse is to be had it must then be via a court at national or regional level. Whether this is feasible will depend on the principles of review that pertain within that system, more particularly those that determine the type of norms that are susceptible to judicial review. There will of course be differences in this respect as between different systems.

The potential claimant is nonetheless likely to face similar difficulties within many legal systems, being caught between a rock and a hard place. If the contested standard is not formally embodied in national or EU legislation, then a court may well simply decide that it is not sufficiently 'public' for the purposes of judicial review, even if compliance with the standard is de facto required for entry to a particular market. If by way of contrast it is incorporated in national or EU legislation then the court may find either that it is unreviewable in legal systems where primary legislation is not subject to judicial review save on limited constitutional grounds, or even if the court is willing to review because the standard is embodied in a secondary national norm it may well do so with a light touch, mindful of the ISO's technical expertise. ${ }^{61}$

The latter is particularly likely to occur in a legal regime such as the EU, where many of the standards are based on ISO standards, and where the Commission has persistently emphasized that it does not determine the detailed content of the standards. It accepts that it does not have the requisite expertise to influence the content of standards, while stressing the 'governmental role' in establishing the objectives and targets, leaving it to the standardization

\footnotetext{
${ }^{61}$ P. Craig, 'Legal Control over Regulatory Bodies: Principle, Policy and Teleology', in P. Birkinshaw and M. Varney (eds.), The European Legal Order after Lisbon (Alphen aan den Rijn: Kluwer Law International, 2010), pp. 112-4.
} 
bodies to decide on the content of the standards and the best way of meeting governmental objectives. Thus the Commission has stated that 'the technical contents of such harmonised standards are under the entire responsibility of the European standardisation organisations', and that EU harmonization legislation does not 'foresee a procedure under which public authorities would systematically verify or approve either at Union or national level the contents of harmonised standards, which have been adopted by European standardisation organisations'. ${ }^{62}$

In regulatory terms, ISO standardization is a quintessential example of shared administration operating between the global, regional and national level. We have already touched on this when describing the ISO regime and the fact that the full members are the principal national standardization bodies, which help shape the standards and sell them. The regulatory interaction is however more far-reaching than this. There is a symbiotic link between ISO and EU standardization, such that 'European standards, including harmonised standards, are often based fully or partially on international ISO or IEC standards' ${ }^{63}$ The resulting EU standards have a real impact on the national level, since they are the most direct way of showing conformity to the essential safety objectives specified in EU legislation. ${ }^{64}$ This symbiotic connection is further formalized through the Vienna and Dresden Agreements made between the ISO and the EU standardization bodies. ${ }^{65}$ Thus the Vienna Agreement

62 The 'Blue Guide' on the Implementation of EU Product Rules 2014, para. 4.1.2.2, http://ec.europa.eu/enterprise/policies/european-standards/links/index_en.htm .

\footnotetext{
${ }^{63}$ The 'Blue Guide' on the Implementation of EU Product Rules 2014, para. 4.1.2.4.

${ }^{64}$ Enhancing the Implementation of New Approach Directives, COM(2003) 240; The 'Blue Guide' on the Implementation of EU Product Rules 2014.

65 Agreement on Technical Co-operation between ISO and CEN (Vienna Agreement), http://www.cencenelec.eu/intcoop/StandardizationOrg/Pages/default.aspx ; IEC-CENELEC Agreement on
} 
recognises the primacy of international standards, but recognizes also that the EU may have particular needs in relation to standardization. The agreement therefore provides for the ISO to take the lead in relation to some standards, while CEN takes the lead on others, with documentation developed by one body being notified for the simultaneous approval by the other.

There is however more to this linkage between standardization organizations than symbiotic interaction. There is the all-important issue of whose standard becomes the ISO accepted norm, with the competition commonly between Europe and the US. Büthe and Mattli argue convincingly that Europe has the edge in this respect, with the consequence that it is US firms that more often must bear the costs of modifications to comply with the new ISO standard. This is because countries or systems with greater domestic coordination and institutional hierarchy in standard setting benefit from greater complementarity, such that they have greater influence on ISO standard setting 'because such domestic institutions facilitate effective interest aggregation and information flows'. ${ }^{66}$

\section{Global Networks and Shared Administration: The Role of National Administrative Law}

The discussion thus far has considered two variants of shared administration that characterize the interplay between the global, regional and national legal orders. The development of precepts of administrative law at the global level has been fostered as a way of alleviating concerns about the accountability and legitimacy of global governance regimes. It is

Common Planning of New Work and Parallel Voting (Dresden Agreement),
http://www.cenelec.eu/aboutcenelec/whoweare/globalpartners/iec.html .

${ }^{66}$ T. Büthe, and W. Mattli, The New Global Rulers, the Privatization of Regulation in the World Economy (Princeton: Princeton University Press, 2011), p. 162. 
nonetheless important to shift the focus to the contribution that national administrative law might make in this respect.

This is in part because certain global regimes, such as the WTO, have provisions mandating judicial review at national level, and it is therefore central to the success of such regimes that this operates efficaciously to ensure, for example, that national authorities comply with their obligations under the respective WTO agreements. It is the national judicial forum through which state accountability is initially secured, in the sense of checking that the state does not seek to, for example, impose anti-dumping duties when they are not warranted, or attempt to engage in covert protectionism through imposition of sanitary constraints on foreign goods for which there is no objective need. National courts should, where the system operates properly, function as the first point of redress, with disputes only going to the WTO settlement mechanism if they cannot be otherwise resolved legally or politically.

There is however a different rationale for paying attention to the potential contribution of national administrative. This is because even if precepts of global administrative law are developed, it is arguable that there will continue to be accountability gaps that can only be filled lower down, whether at the regional or national level or both.

Thus Stewart in his seminal study notes the dramatic shift of regulatory authority from the nation state to a 'dizzying variety of global regulatory regimes', the result being that 'domestic systems of administrative accountability through law are being increasingly sidestepped' by regulatory norms produced by global regimes that are not subject to such disciplines, which are then implemented through domestic regulation. ${ }^{67}$ This in turn can exacerbate the danger that the global regulatory process will be captured by powerful, well-

\footnotetext{
${ }^{67}$ R.B. Stewart, 'The Global Regulatory Challenge to U.S. Administrative Law' (2005) 37 New York University Journal of International Law and Policy 695.
} 
organized interests, to the detriment of consumer groups, environmentalists and the like. The problem is exemplified by the fact that. ${ }^{68}$

A government agency that determines capital adequacy requirements for banks, runs a pollution credit trading system, or freezes the assets of suspected terrorists would typically be subject to some form of administrative law procedures for decision-making that would afford the right to present evidence and argument by those affected, and to review by a court. These rights do not exist for the Basel Committee, the Kyoto Protocol Clean Development Mechanism Executive Board, and the Security Council's 1267 Al Qaeda Sanctions Committee respectively.

Shapiro also considers the issues raised by international standardization, WTO adjudication and equivalency obligations, on the normal regime for accountability of regulation in the US. He argues that compliance with the Administrative Procedure Act 1946 notice and comment requirements may be ineffective in achieving citizen participation in the development of an international harmonized regulation, since the APA does not require an agency to seek public input in advance of agreeing to a harmonized standard, and when the agreement has been made, 'there is an international commitment by the United States to adopt the harmonized regulation, which creates a substantial disincentive to change or amend the international standard during rulemaking'. ${ }^{69}$ In relation to the WTO, Shapiro contends that public participation in the US may be frustrated because any amended rule that an agency proposes to comply with a WTO result may effectively be a fait accompli, coupled with the lack of public participation in the WTO dispute resolution process. ${ }^{70}$

Wallach voices analogous concerns that 'harmonization moves decision-making away from accessible, accountable state and national governance fora to international bodies that are largely inaccessible to citizens and generally operate without accountability to those who must live with their decisions', more especially given that 'standard-setting requires not only

\footnotetext{
${ }^{68}$ Ibid p. 702, although there have been some improvements in these areas since the article was written in 2005.

${ }^{69}$ S. Shapiro, 'International Trade Agreements, Regulatory Protection, and Public Accountability' (2002) 54 Administrative Law Review 435, 441.

${ }^{70}$ Ibid p. 449.
} 
scientific knowledge, but also subjective policy decisions about the level of risk a society is willing to accept'. ${ }^{71}$ In similar vein, Aman notes that 'the democratic processes used to conform domestic law to an international ruling may, in reality, be substantially less than those used to create these rules or laws in the first place', as exemplified by the fact that although amendment to domestic law to comply with WTO imperatives will be undertaken through a process that appears democratic, 'the outcomes usually are a foregone conclusion' given the prior Treaty commitments. ${ }^{72}$

There are various possible responses to such concerns. It might be argued that there is no such accountability gap, provided that the precepts of global administrative law really are properly developed and applied at the international or transnational level, although such an argument would be difficult to sustain in empirical and normative terms. The preceding critiques might alternatively be accepted, subject to the caveat that the negative effect on domestic regulatory processes is inevitable to some degree in any sphere where international law broadly conceived impacts on national law. It might by way of contrast be contended that the negative impact on domestic regulatory mechanisms is regrettable, but no more so than the converse accountability gap that exists when domestic regulations are made without taking cognizance of their effect on outsiders, the disjunction between regulatory jurisdiction and regulatory impact noted earlier. A further possibility is to acknowledge the problem, but attempt 'to do something' about it, albeit being mindful of the difficulties involved.

It is worth dwelling on this latter strategy, which coheres with the very idea of shared administration adumbrated above. Given that global regulatory initiatives will commonly

\footnotetext{
${ }^{71}$ L. Wallach, 'Accountable Government in the Era of Globalization: The WTO, NAFTA and the International Harmonization of Standards' (2002) 50 University of Kansas Law Review 823, 863.

72 Aman, A., The Democracy Deficit, Taming Globalization through Law Reform (New York: New York University Press, 2004), p. 4.
} 
entail some form of shared administration with the regional or national level, it is unsurprising that administrative law mechanisms to enhance accountability might have to be fashioned for the global level and adjusted at the regional and/or national level.

Of relevance in this respect is Barack Obama's Executive Order made in 2012, designed to foster international regulatory co-operation. ${ }^{73}$ The general policy underlying the Order is promote such cooperation and encourage compromise between U.S. regulatory agencies and their foreign counterparts, in order to prevent, reduce or eliminate unnecessary differences in regulatory requirements. To this end, agencies are charged with ensuring that significant regulations that have significant international impacts are designated as such, and the agencies must consider eradication of unnecessary regulatory differences when pointed out by stakeholders.

A decade earlier, the American Bar Association was cognizant of the need for adjustment of national administrative law, recommending in 2001 that the President should seek to ensure effective public participation by encouraging federal agencies to list at an appropriate time significant harmonization activities in their annual regulatory agendas or some analogous medium. The ABA recommended that agencies should invite the public to comment on new and ongoing significant harmonization activities, including attendance at meetings concerning such activities; refer significant harmonization issues to advisory committees where appropriate and feasible; and make documents available under the Freedom of Information Act (FOIA) relating to each significant harmonization activity. ${ }^{74}$

\footnotetext{
${ }^{73}$ Exec. Order No. 13,609, 77 Fed. Reg. 26,413, (May 1, 2012).

${ }^{74}$ S. Shapiro, 'International Trade Agreements, Regulatory Protection, and Public Accountability' (2002) 54 Administrative Law Review 435, 444-5.
} 
From an academic perspective it is Stewart who has worked through the implications of increased global regulation for national administrative law in most detail. ${ }^{75} \mathrm{He}$ articulates three possible models of interaction. The first he terms the 'bottom up' approach, whereby domestic administrative law is applied so as to assert more effective control of the supranational elements of domestic regulation by, for example, extending national administrative law process requirements and judicial review to decisions and norms of global regimes implemented by U.S. agencies, or by insisting that the agency address the global elements in its decision, and include them in its review. The second model is 'top down', whereby the global regulatory regimes develop more fully the type of administrative law safeguards commonly found in national systems, in the manner considered in the first half of this chapter. Stewart's third model of global administrative law follows an 'integrative' logic 'through substantive principles and regulatory due process requirements applicable to decisions by domestic agencies that affect international trade and investment, aliens, and other extra-national interests' ${ }^{76}$

Aman has also made valuable suggestions in this respect. Thus he urges that 'administrative rule-making processes should include an explicit direction to consider seriously the global implications of proposed rules', which would 'not only encourage participants to indicate the transboundary effects of a rule but also provide a domestic forum to raise the issue'. Aman, in accord with the ABA's approach, also seeks to shift the focus from post-hoc compliance with the demands of standardization or WTO rulings, to 'the much

\footnotetext{
75 R.B. Stewart, 'The Global Regulatory Challenge to U.S. Administrative Law' (2005) 37 New York University Journal of International Law and Policy 695; R.B. Stewart, 'Remedying Disregard in Global Regulatory Governance: Accountability, Participation, and Responsiveness' (2014) 108 American Journal of International Law 211.

${ }^{76}$ R.B. Stewart, 'The Global Regulatory Challenge to U.S. Administrative Law' (2005) 37 New York University Journal of International Law and Policy 695, 710-11.
} 
earlier stages in the decision-making processes when a dialogue on how best to mesh domestic law with likely WTO requirements can take place within domestic political institutions' ${ }^{77}$

Space precludes detailed discussion of such initiatives. Suffice it to say that this is not a zero-sum game, and these initiatives should therefore be regarded as operating in tandem with developments to enhance accountability at the global level of the kind analysed in the first half of this chapter. There are perforce limits as to the transferability of such specific proposals to other states, which have very different domestic mechanisms for securing rulemaking accountability. This does not however undermine the underlying thrust of this approach, drawing as it does on national and global administrative law.

\section{Conclusion}

The development of global governance institutions, whether pursuant to traditional international treaties, or more informal transnational regulatory networks, raises numerous concerns, including the fear of domination of decision-making by unelected experts, the lack of transparency, and the circumvention of the normal rules of representative democracy, allowing policy to be developed without the imprimatur of the elected legislature. The development of principles of global administrative law is not a panacea that can resolve all such issues. The reality is that global governance, whether through international organizations or transnational regulatory networks, is not going to disappear, and global replication of national electoral models is empirically unlikely and normatively problematic. The development of principles of global administrative law can, however, contribute to the

\footnotetext{
${ }^{77}$ Aman, A., The Democracy Deficit, Taming Globalization through Law Reform (New York: New York University Press, 2004), pp. 150-1, 161-2.
} 
development of more accountable global governance, the value of which should not be underestimated

\section{Bibliography}

Aman, A., The Democracy Deficit, Taming Globalization through Law Reform (New York: New York University Press, 2004);

Aman, A., 'Globalization, Democracy and the Need for a New Administrative Law' (2003) 10 Indiana Jnl of Global Legal Studies 125;

Battini, S., 'The Proliferation of Global Regulatory Regimes', in S. Cassese (ed.), Global Administrative Law, A Research Handbook, Pt. I, Chap. 2;

Büthe, T. and Mattli, W., The New Global Rulers, the Privatization of Regulation in the World Economy (Princeton: Princeton University Press, 2011);

Cassese, S., 'Global Standards for National Administrative Procedure' (2005) 68 Law and Contemporary Problems 109;

Cassese, S., 'Administrative Law without the State? The Challenge of Global Regulation' (2005) 37 New York University Journal of International Law and Policy 663;

Cassese, S., The Global Polity, Global Dimensions of Democracy and the Rule of Law (Sevilla: Global Law Press, 2012);

Committee of Independent Experts, Second Report on Reform of the Commission, Analysis of Current Practice and Proposals for Tackling Mismanagement, Irregularities and Fraud (10 September 1999);

Craig, P., 'Legal Control over Regulatory Bodies: Principle, Policy and Teleology', in P. Birkinshaw and M. Varney (eds.), The European Legal Order after Lisbon (Alphen aan den Rijn: Kluwer Law International, 2010), Chap. 5; 
Craig, P., 'Shared Administration and Networks: Global and EU Perspectives', in G. Anthony, J-B. Auby, J. Morison and T. Zwart (eds.), Values in Global Administrative Law, Essays in Honour of Spyridon Flogaitis and Gerard Timsit (Hart, 2011), Chap. 4;

Craig, P., UK, EU and Global Administrative Law: Foundations and Challenges (Cambridge: Cambridge University Press, 2015);

della Cananea, G., 'The European Union's Mixed Administrative Proceedings' (2004) 68 Law and Contemporary Problems 197;

Dunoff, J.L., 'Constitutional Conceits: The WTO's 'Constitution' and the Discipline of International Law’ (2006) 17 European Journal of International Law 647;

Kingsbury, B., Krisch, N., and Stewart, R.B., 'The Emergence of Global Administrative Law' (2005) 68 Law and Contemporary Problems 15;

Marchetti, B., 'Enforcement of Global Decisions', in S. Cassese (ed.), Global Administrative Law, A Research Handbook, Pt III, Chap. 4;

Mattli, W., and Büthe, T., 'Setting International Standards: Technological Rationality or Primacy of Power' (2003) 56 World Politics 1;

Raustiala, K., 'The Architecture of International Cooperation: Transgovernmental Networks and the Future of International Law' (2002) 43 Virginia Journal of International Law 1;

Scott, J., 'Cooperative Regulation in the WTO: The SPS Committee', Global Law Working Paper, 3/06, Hauser Global Law School Program-NYU School of Law;

Shaffer, G., 'How the WTO Shapes Regulatory Governance', University of California, Irvine, Legal Studies Research Paper Series No. 2014-53;

Shapiro, S., 'International Trade Agreements, Regulatory Protection, and Public Accountability' (2002) 54 Administrative Law Review 435;

Slaughter, A-M., A New World Order (Princeton: Princeton University Press, 2004); 
Stewart, R. B., 'The Global Regulatory Challenge to U.S. Administrative Law' (2005) 37 New York University Journal of International Law and Policy 695;

Stewart, R.B., 'US Administrative Law: A Model for Global Administrative Law?' (2005) 68 Law and Contemporary Problems 63;

Stewart, R.B., 'Remedying Disregard in Global Regulatory Governance: Accountability, Participation, and Responsiveness' (2014) 108 American Journal of International Law 211; von Bogdandy, A., and Dann, P., 'International Composite Administration: Conceptualizing Multi-Level and Network Aspects in the Exercise of International Public Authority' (2008) 9(11) German Law Jnl 2013;

Wallach, L., 'Accountable Government in the Era of Globalization: The WTO, NAFTA and the International Harmonization of Standards' (2002) 50 University of Kansas Law Review 823. 